\title{
The Impact of Cattle Grazing in High Elevation Sierra Nevada Mountain Meadows over Widely Variable Annual Climatic Conditions
}

\author{
Lindsey Myers", Brenda Whited \\ Central Sierra Environmental Resource Center (CSERC), Twain Harte, USA. \\ Email: *lindseym@cserc.org, whitedb@yosemite.edu \\ Received May $18^{\text {th }}, 2012$; accepted June $19^{\text {th }}, 2012$; accepted July $17^{\text {th }}, 2012$
}

\begin{abstract}
The impact of summer cattle grazing on water quality during three very different climatic years in the Sierra Nevada was investigated. Water year 2009 had near normal precipitation; 2010 had late precipitation and snowmelt; and 2011 had $150 \%$ above normal precipitation. Surface waters were tested for pathogenic bacteria indicators fecal coliform, $E$. coli, and total coliform before and after cattle were released onto summer grazing allotments. Water samples were collected from meadow stream sites up to 6 weeks before and up to 6 weeks after cattle grazing began. Streams passing through ungrazed meadow served as controls. Eight sample sites were between $1694 \mathrm{~m}$ and $2273 \mathrm{~m}$ in elevation; one site was lower at $1145 \mathrm{~m}$ in elevation. Samples were transported within 6 hours to a water analysis laboratory, where samples were analyzed following standardized laboratory methods. Results showed that individual site and total mean concentrations of $E$. coli in surface waters were within regulatory standards before cattle arrived during each of the 3 study years. After the beginning of grazing, mean E. coli counts increased as follows: 2009 from 8 to $240 \mathrm{CFU} / 100 \mathrm{~mL}$, 2010 from 7 to $561 \mathrm{CFU} / 10 \mathrm{~mL} ; 2011$ from 7 to $657 \mathrm{CFU} / 100 \mathrm{~mL}$ ( $\mathrm{p}<0.05$ all years). Total coliform bacteria and fecal coliform concentrations showed the same pattern. This study shows that cattle grazing in the high elevation Sierra Nevada results in a significant increase in indicator bacteria. This impact on the watersheds occurs despite widely variable annual climatic conditions.
\end{abstract}

Keywords: Water Quality; Sierra Nevada, Mountain Meadows; Livestock Grazing; Cattle, Indicator Bacteria

\section{Introduction}

The Sierra Nevada is a dominant land feature of the state of California, spanning $640 \mathrm{~km}$ (400 miles) north-tosouth and 97 to $129 \mathrm{~km}$ (60 to 80 miles) east-to-west [1]. With 500 peaks above $3658 \mathrm{~m}$, this region's rugged topography and other natural resources attracts 50 to 60 million recreational visitors every year [2]. Some notable Sierra landmarks include: Lake Tahoe, the largest alpine lake in lower North America; Mount Whitney, the highest peak in North America at 4418 m, and world-renowned Yosemite Valley. The mountain range provides more than half of California's fresh surface water and acts as a natural reservoir [3,4]. Water from Sierra winter storms accumulates into snowpack, primarily between $1600 \mathrm{~m}$ and $4400 \mathrm{~m}$. It then melts slowly through spring and into summer to fill streams and reservoirs that sustain the state's ever-growing population and the enormous needs of lowland agriculture during the dry summer months. The Sierra Nevada's greatest economic

\footnotetext{
${ }^{*}$ Corresponding author.
}

value comes from the abundant amount of essential fresh water the range provides to California [5].

The future dependability of this important watershed is uncertain as climate change is anticipated to increase air temperature in the Sierra Nevada causing direct impacts to the water supply [4-7]. Decreases in mean annual flow, reduced snowpack as precipitation shifts to rainfall from snowfall, and more rapid snowmelt runoff are expected with increased air temperature $[4,6,8]$.

California's population increased ten percent from 2000 to 2010 , to nearly 38 million in 2011 [9]. As the state's population increases, so does the demand on the limited supply of fresh water that is available [3]. Threats to Sierra Nevada watersheds include urban development, logging, mining, certain recreational uses, air pollution from the Central Valley, and summer season cattle grazing. Many experts agree that cattle grazing poses the greatest threat to water quality in undeveloped high elevation areas [10-12]. The water ecology of these areas is highly sensitive to degradation by cattle because 1) cattle cluster in stream or wetland areas, 2) there is limited or 
absent filtering topsoil, 3) cattle manure adds phosphates and nitrates into naturally oligotrophic bodies of water, 4) there is a short growing season, and 5) cattle cause erosion of natural stream banks, depleting the already limited top soil [13-20].

It has been well documented that cattle manure can introduce pathologic microorganisms such as Giardia, Cryptosporidium, Campylobactor, Salmonella, enterotoxic strains of Escherichia coli (E. coli), or other harmful bacteria into water [21-24]. Serious microbial water quality degradation in the Sierra Nevada, including the Stanislaus National Forest (STF), has been linked to summer cattle grazing, when manure is washed into lakes and streams or directly deposited into these bodies of water $[20,25]$. However, many of the earlier studies in the Sierra have been single point in time analysis, only sampling for fecal indicator bacteria after livestock exposure.

Continuous weekly analysis of stream water in cattle grazing areas both before and after the arrival of cattle would better demonstrate a cause and effect of grazing. Our research group performed such a preliminary analysis during the summer of 2009 [26]. We found a dramatic rise in indicator bacteria from a 6-week analysis before cattle arrived in alpine meadows compared with the 6-week period after grazing began. Multiple violations of state water quality standards were also found in grazed areas after cattle arrived. Our study only represented a single season, and seasonal precipitation and snowmelt varies widely in the Sierra $[1,3]$. Therefore the current study reported here extends our analysis of water quality over three very different climatic years.

\section{Methods}

Water sampling occurred exclusively in the Stanislaus National Forest (STF). The STF is located in the Sierra Nevada region of California, bordering the west and north sides of Yosemite National Park. The STF is extremely popular for outdoor recreation-fishing, hiking, camping, backpacking, swimming, rafting, canoeing, and a wide range of other outdoor recreation activities that bring more than 2,000,000 visitors each year to the forest (USDA 2009b). Within the STF itself, there are 811 miles of rivers and streams and a reservoir capacity of 768,000 acre-feet [27].

Four major watersheds are partially within the STF: the Tuolumne, Stanislaus, Mokelumne and Merced River. The Stanislaus and Tuolumne River watersheds each provide about three million acre-feet of water storage for recreation, agriculture, domestic supply, and other uses per year [28]. The Mokelumne and Merced River watersheds each provide close to a million acre-feet of water storage for recreation, agriculture, domestic supply, and other uses per year [28]. These four rivers flow into the San Joaquin River.

\subsection{Field Site Selection}

Livestock grazing on National Forest System lands is authorized by a grazing or livestock permit, which is issued for a ten-year term [29].

Each year our research group studied three to four grazed sites in addition to control sites where no grazing occurred. Grazed sites varied each year in accordance with which allotments were being grazed. Any given year an allotment may not be grazed as the permittee (a rancher who is issued a permit to graze livestock on Federal land) can choose not to bring cattle to the forest for summer grazing. A permittee may opt for a non-use year for a variety of reasons, such as a shortened summer grazing season due to a late spring with heavy snowpack as happened in 2010 and 2011. For example, the Long Valley/Eagle Meadow Allotment was grazed in 2009, but not grazed in 2010 and 2011.

Sample sites were selected to be representative of the several microclimates within the STF, and needed to be accessible in the six-hour holding time restraint for the bacteriological samples. Two sampling methods were used.

Method A: Collect water samples from a single location on a stream before cattle were released into the forest (the "before" samples) and during the time when cattle were present (the "after" samples).

Method B: A fence around the headwaters of the stream allowed for the "before" grazing samples and "after" grazing samples to be collected on the same date. Samples were first collected downstream of the fenced area, where cattle had access to the stream (the "outside fence/after" site). A sample was then collected on the same stream inside the fence where cattle did not have access (the "inside fence/before" site).

In 2009, four high elevation sites were sampled using Method A. Three sites were sampled in 2010 and 2011. In 2010, two sites were sampled using Method A; the third site was sampled using Method B. In 2011, one site was sampled using both Methods, and the other two sites were sampled using Method B. All of the sites are typical of grazed areas throughout the STF, and are also open and used for public recreation. All streams sampled are designated for "water contact recreation" (among other beneficial uses) by the California Regional Water Quality Control Board. One control site that was not subject to cattle grazing was also tested. The sites are described below. Table 1 provides location (i.e., latitude, longitude) coordinates for each site, using datum NAD 83. Figure 1 
Table 1. List of water sample sites (lat/long datum NAD 83).

\begin{tabular}{cccc}
\hline Site name & County & Latitude & Longitude \\
\hline BM & Tuolumne & 38.29252616 & -119.86239033 \\
BR & Tuolumne & 38.24923656 & -119.96476128 \\
UFG & Tuolumne & 38.22421197 & -119.96850279 \\
LRM & Tuolumne & 38.15877200 & -119.95698600 \\
LRM (upstream sample site) & Tuolumne & 38.16985000 & -119.95798333 \\
BoM (control) & Tuolumne & 38.10920712 & -119.91242115 \\
Bog 1 (outside fence/after cows) & Tuolumne & 37.89369444 & -120.05788889 \\
Bog 2 (inside fence/before cows) & Tuolumne & 37.98830556 & -119.96372222 \\
JC & Tuolumne & 38.00974167 & -119.96610278 \\
RC & Tuolumne & 38.14194962 & -120.19911384 \\
CMUP (outside fence/after cows) & Tuolumne & 37.99208333 & -119.94273333 \\
CMUP2 (inside fence/before cows) & Tuolumne & 37.99241666 & -119.94275000 \\
\hline
\end{tabular}

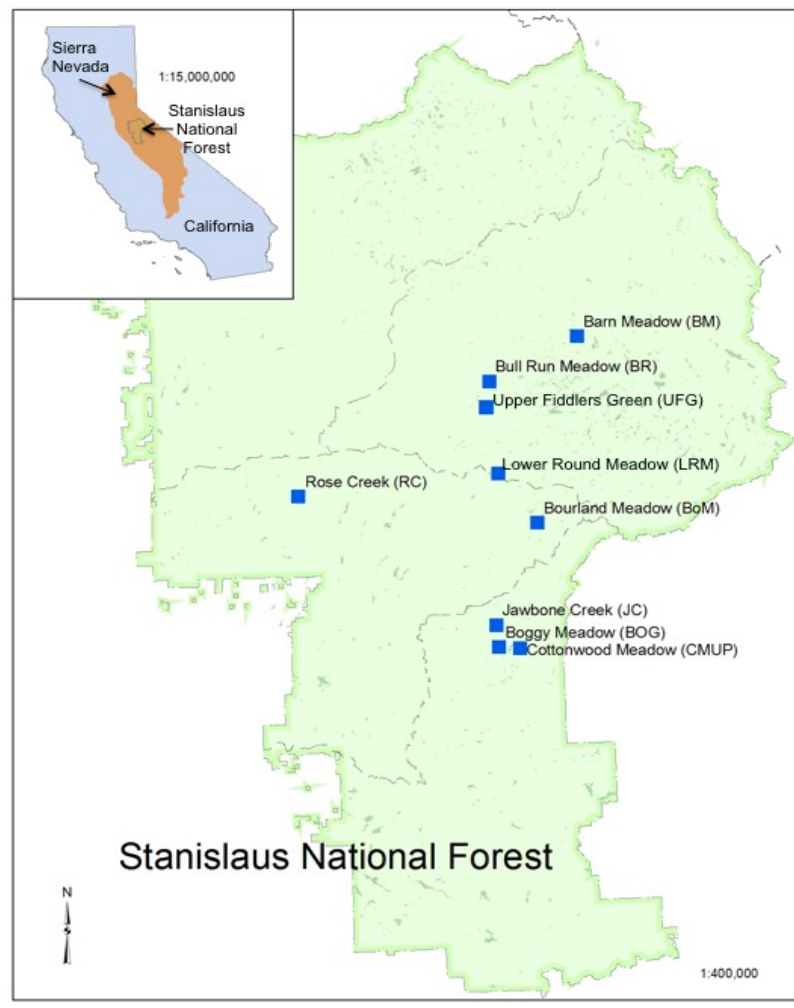

Figure 1. Vicinity area map.

provides a vicinity area map.

\section{Sample sites:}

Lower Round Meadow (site ID-LRM)—1932 m elevation

Method A was used to collect water samples from a tributary stream of the Tuolumne River. Nine "before" grazing water samples and eight "after" livestock arrival water samples were collected. This site is in the Bell Meadow/Bear Lake Range Allotment.

Upper Fiddlers Green Meadow (site ID-UFG) - 1966 m elevation

Method A was used to collect water samples from a tributary stream of the Stanislaus River. Eight "before" grazing water samples and seven "after" livestock arrival water samples were collected. This site is in the Herring Creek Range Allotment.

Bull Run Meadow (site ID-BR)—2022 m elevation

Method A was used to collect water samples from a tributary stream of the Stanislaus River. Eight "before" grazing water samples and nine "after" livestock arrival water samples were collected. This site is in the Herring Creek Range Allotment.

Barn Meadow (site ID-BM) - 2273 m elevation

Method A was used to collect water samples from a tributary stream of the Stanislaus River. Seven "before" grazing water samples and fifteen "after" livestock arrival water samples were collected. This site is in the Long Valley/Eagle Meadow Range Allotment.

Bourland Meadow - control site, not grazed (site IDBoM) - 2225 m elevation

Samples were collected from a tributary stream of the Tuolumne River. Bourland Meadow lies within a designated Research Natural Area (RNA); livestock grazing is not authorized in this area. Eight control water samples were collected during the same time that "after" samples were being collected at the other 2009 study sites.

2010 Sample Sites:

Rose Creek $(R C)$-1145 m elevation 
Method A was used to collect water samples from a tributary stream of the Stanislaus River. Three "before" water samples were and sixteen "after" livestock arrival water samples were collected. This site is within the Rushing Range Allotment.

Jawbone Creek (JC)-1733 m elevation

Method A was used to collect water samples from a tributary steam of the Tuolumne River. Six "before" grazing water samples and seven "after" livestock arrival water samples were collected. This site is within the Rosasco Range Allotment.

Boggy Meadow 1 \& 2 (Bog 1 \& Bog 2)—Bog 1: 1694 m elevation; Bog 2: 1695 m elevation

Method B was used to collect two water samples from a tributary stream of the Tuolumne River. Eight "inside fence/before" and "outside fence/after" grazing water samples were collected. This site is within the Roasaco Range Allotement.

Bourland Creek - control site, not grazed (BoM) 2225 m elevation

This site was also used as the control in 2009. Six control water samples were collected at this site during the same time that "after" samples were being collected at the other study sites in 2010 .

2011 Sample Sites:

Boggy Meadow 1 \& 2 (Bog 1 \& Bog 2) Bog 1-1694 m elevation; Bog 2-1695 m elevation

This site was also sampled in 2010 using Method B. Twelve "inside fence/before" and "outside fence/after" grazing water samples were collected in 2011.

Cottonwood Meadow (CMUS \& CMUS2)-CMUS: 1733 m; CMUS2: 1767 m elevation

Method B was used to collect two water samples from a tributary stream of the Tuolumne River. Five "inside fence/before" grazing water samples and six "outside fence/after" cattle arrival water samples were collected. This site is within the Rosasco Range Allotment.

Lower Round Meadow (LRM) - 1932 m elevation

This site was sampled in 2009 using Method A. Method A and B were used to sample this site in 2011. One "before" grazing water sample and eleven "after" livestock arrival water samples were collected from the same location. In addition, twelve "before" livestock samples were collected from an ungrazed forested area upstream of the LRM sample site.

Bourland Meadow (control site, not grazed) $-2225 \mathrm{~m}$ elevation

Control water samples were also collected at this site in 2009 and 2010. One-control water sample was collected at this site in 2011.

Additional Control Sites: The UFG, BR, and BM sample sites had "before" and "after" grazing samples collected during the summer of 2009. These sample sites were not grazed in 2011. Control water samples were collected (three at UFG and BR, four at BM) during the same time period that cattle would have been present if these areas had been grazed.

\subsection{Field Water Collection}

A Quality Assurance Project Plan (QAPP) was prepared for this water-monitoring project, and all procedures specified in the QAPP were followed [30].

Water samples that were collected for bacteriological testing were collected while wearing sterile gloves and collected in sample bottles sterilized and provided by a certified microbiology lab (lab) (which has Environmental Laboratory Accreditation Program [ELAP] certification). The bacteriological samples were collected before any other work was performed at the site. The sterilized Nalgene bottles hold $125 \mathrm{~mL}$ of liquid. They were filled to $100 \mathrm{~mL}$ with sample water taken directly from flowing water approximately $0.1 \mathrm{~m}$ below the surface. The collection date, time, and samplers' names were recorded on the field datasheets, which are retained at the CSERC office; they are also recorded on the Chain-of-Custody form that was transmitted to the lab along with each sample. No sampling bottles were contaminated during sampling or transit.

All water samples collected for bacteriological analyses were delivered to the lab within six hours from the time the samples were collected in the field. The sample bottles were placed in Zip-loc plastic bags (to avoid potential contamination from the ice water) on ice in a cooler until delivered into the custody of the lab. While collecting the water samples, the relative flow of the stream being sampled was recorded on a field datasheet along with other observations about the sample area.

\subsection{Laboratory Analyses}

Water samples were delivered to a State-certified analytical laboratory in Twain Harte, CA. All water samples were tested for total coliform, fecal coliform, and E. coli bacteria using Multiple Tube Fermentation (Most Probable Number $/ 100 \mathrm{~mL}$ ). The detection limit using this method of analysis is two-organisms $/ 100 \mathrm{~mL}$ of water. The detection maximum using this method of analysis is 1600 -organisms $/ 100 \mathrm{~mL}$ of water. The analytical methods utilized by this laboratory are specified in Standard Methods for the Examination of Water and Wastewater $\left(19^{\text {th }}\right.$ Edition).

\subsection{Data Analysis}

For each response variable total coliform (TC), fecal coliform (FC), and E. coli (EC) Colony Forming Unit 
(CFU)/100mL) the data was transformed using log (base e) to normalize the residuals. To determine the effect of year $(2009,2010$, and 2011) and before grazing/after grazing/control (no grazing) on the response variables, a full factorial analysis of variance was performed (JMP IN 10, SAS Institute Inc.). This model analyzes the effect of year on the overall response variable (combined before/after/control measurements), the effect of grazing (before/after/control) on the overall response variable (combined years), and the interaction of year and grazing. For example, a significant interaction could occur if $\mathrm{FC} / 100 \mathrm{~mL}$ after grazing significantly increased from 2009 to 2010 while before and control values did not. To compare mean TC, FC and EC for the before/after effect, a Tukey's HSD mean comparison test was performed. For measurements below (i.e., $<2$ Colony-Forming Units $(\mathrm{CFU}) / 100 \mathrm{~mL}$ ) or above (i.e., $>1600 \mathrm{CFU} / 100 \mathrm{~mL}$ ) the laboratory detection limits, the value for that sample was conservatively assumed to be equal to the limit (i.e., 2 or $1600 \mathrm{CFU} / 100 \mathrm{~mL}$, respectively).

The bacteria results were compared to the relevant water quality standards contained in the Central Valley Regional Water Quality Control Board's Water Quality Control Plan for the Sacramento and San Joaquin River Basins ("Basin Plan") [31].

In waters designated for contact recreation (REC-1), the fecal coliform concentration based on a minimum of not less than five samples for any 30-day period shall not exceed a geometric mean of $200 / 100 \mathrm{ml}$, nor shall more than ten percent of the total number of samples taken during any 30-day period exceed 400/100ml. (Basin Plan at III-3) [31].

Data was compiled for representative 30 -day periods, and results were judged as a "Type 1 Violation" whenever the geometric mean of five samples collected over a 30-day period exceeded 200 fecal coliform colonies per $100 \mathrm{ml}$ of water. Results were judged as a "Type 2 Violation" whenever more than ten percent of the samples collected over a 30-day period exceeded 400 fecal coliform colonies per $100 \mathrm{ml}$ of water.

\subsection{Weather Data}

Precipitation data was obtained from weather stations located in the Stanislaus National Forest, accessed through the California Department of Water Resources Data Exchange Center [32]. Data from three weather stations will be discussed. Two stations located within the Stanislaus River basin, one at $1707 \mathrm{~m}$ located near Pinecrest, the other at $2560 \mathrm{~m}$ located near Gianelli Meadow. The third is located within the Tuolumne River basin at $2560 \mathrm{~m}$ elevation located near Horse Meadow.

\section{Results}

The results of our study are displayed in Figures 2-4. Each of the three study years produced consistent results: indicator bacteria were at very low levels before the arrival of cattle and at control sites, and increased to substantially higher levels after the arrival of cattle. The elevated levels of indicator bacteria fluctuated between samples but remained higher than before or control samples for the duration of the grazing season.

Figure 2 shows the mean level of fecal coliform before cattle were present and after the introduction of cattle by year. Each year fecal coliform increased after cattle were present. In 2009 the mean fecal coliform for the

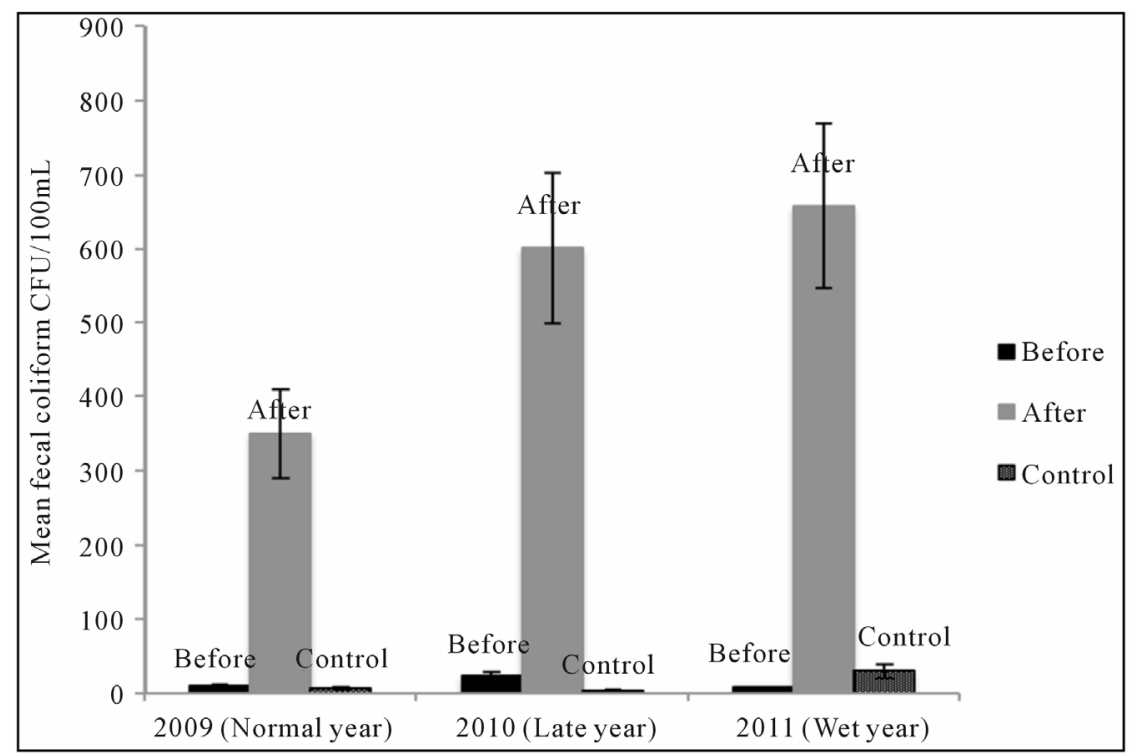

Figure 2. Mean fecal coliform by year. 
four sites tested increased from $9 \mathrm{CFU} / 100 \mathrm{~mL}$ (Std Err $=$ $3, \mathrm{n}=33$ ) before cattle were present to $350 \mathrm{CFU} / 100 \mathrm{~mL}$ (Std Err $=58, n=40)$ after the introduction of cattle. In 2010 the mean level of fecal coliform increased from 23 $(\operatorname{Std} \mathrm{Err}=16, \mathrm{n}=19)$ to $601 \mathrm{CFU} / 100 \mathrm{~mL}(\mathrm{Std} \mathrm{Err}=106$, $\mathrm{n}=36)$ at the three sites tested. In 2011 the mean level of fecal coliform increased from 7 ( $\operatorname{Std}$ Err $=2, n=25$ ) to $657($ Std $\mathrm{Err}=113, \mathrm{n}=34) \mathrm{CFU} / 100 \mathrm{~mL}$ at the three sites tested. The mean level of fecal coliform at the control site(s) was $6($ Std Err $=2, \mathrm{n}=8)$ in 2009, $3($ Std Err $=1$, $\mathrm{n}=6)$ in 2010, and $29 \mathrm{CFU} / 100 \mathrm{~mL}(\operatorname{Std} \mathrm{Err}=9, \mathrm{n}=11)$ in 2011 .

Figure 3 shows the mean level of $E$. coli before cattle were present and after the introduction of cattle by year. Similar to fecal coliform, each year the level of E. coli increased after cattle were present. In 2009 the mean $E$. coli for the four sites tested increased from $8 \mathrm{CFU} / 100$ $\mathrm{mL}(\mathrm{Std} \mathrm{Er}=3, \mathrm{n}=33)$ before cattle were present to more than $240 \mathrm{CFU} / 100 \mathrm{~mL}(\mathrm{Std} \mathrm{Err}=32, \mathrm{n}=40)$ after the introduction of cattle. In 2010 the mean level of $E$. coli increased from 7 (Std Err $=3, \mathrm{n}=19)$ to $560(\mathrm{Std}$ Err $=103, \mathrm{n}=36) \mathrm{CFU} / 100 \mathrm{~mL}$ at the three sites tested. In 2011 the mean level of E. coli increased from 7 (Std Err $=1, \mathrm{n}=25)$ to $600($ Std Err $=108, \mathrm{n}=34) \mathrm{CFU} / 100$ $\mathrm{mL}$ at the three sites tested. The mean level of $E$. coli at the control site(s) is 5 ( $\mathrm{Std} \mathrm{Err}=2, \mathrm{n}=8)$ in 2009, 2 ( $\mathrm{Std}$ Err $=0, \mathrm{n}=6)$ in 2010 , and $25 \mathrm{CFU} / 100 \mathrm{~mL}(\operatorname{Std} \mathrm{Err}=8$, $\mathrm{n}=11)$ in 2011 .

Figure 4 shows the mean level of total coliform before cattle were present and after the introduction of cattle by year. Similar to E. coli and fecal coliform, coliform in- creased after cattle were present. In 2009 the mean coliform for the four sites tested increased from $243 \mathrm{CFU} /$ $100 \mathrm{~mL}(\mathrm{Std} \mathrm{Err}=70, \mathrm{n}=33)$ before cattle were present to $670 \mathrm{CFU} / 100 \mathrm{~mL}$ (Std Err $=92, \mathrm{n}=40$ ) after the introduction of cattle. In 2010 the mean level of coliform increased from $122(\operatorname{Std} \mathrm{Err}=83, \mathrm{n}=19)$ to $689 \mathrm{CFU} /$ $100 \mathrm{~mL}(\mathrm{Std}$ Err $=110, \mathrm{n}=36)$ at the three sites tested. In 2011 the mean level of coliform increased from 48 ( Std $\mathrm{Err}=18, \mathrm{n}=25)$ to $699 \mathrm{CFU} / 10 \mathrm{~mL}(\mathrm{Std} \mathrm{Err}=110, \mathrm{n}=$ $34)$ at the three sites tested. The mean level of coliform at the control site(s) is 44 ( $\mathrm{Std} \operatorname{Err}=18, \mathrm{n}=8)$ in 2009, 33 $($ Std Err $=4, \mathrm{n}=6)$ in 2010 , and $90 \mathrm{CFU} / 100 \mathrm{~mL}$ (Std Err $=27, \mathrm{n}=11)$ in 2011 .

\subsection{Ungrazed Control Site}

In comparison to the significant increase in fecal coliform and E. coli colonies quantified at the streams in grazed areas once livestock were present, the fecal coliform and E. coli concentrations at Bourland Meadow (the control site across all three years) remained consistently low and within standard limits throughout the same time period that the grazed samples were being collected (see Figures 2 and 3). In 2009, the mean level of fecal coliform was $6 \mathrm{CFU} / 100 \mathrm{~mL}$, and the mean level of $E$. coli was less than $5 \mathrm{CFU} / 100 \mathrm{~mL}$. In 2010 , the mean level of fecal coliform was $3 \mathrm{CFU} / 100 \mathrm{~mL}$ and the mean level of E. coli was $2 \mathrm{CFU} / 100 \mathrm{~mL}$. In 2011, the site was sampled one time. The fecal coliform and E. coli level was less than $2 \mathrm{CFU} / 100 \mathrm{~mL}$. As noted previously, Bourland Meadow is managed as a Research Natural Area that does not have any permitted livestock grazing. Otherwise,

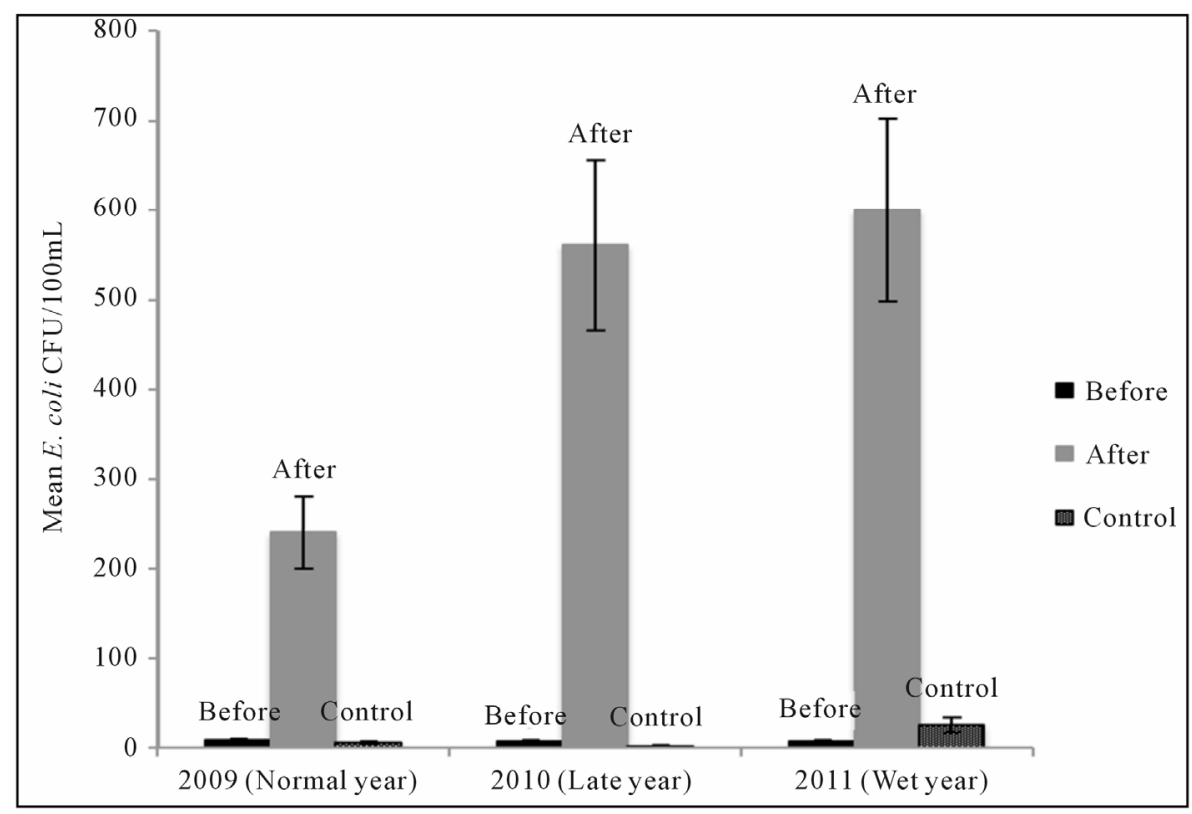

Figure 3. Mean E. coli by year. 


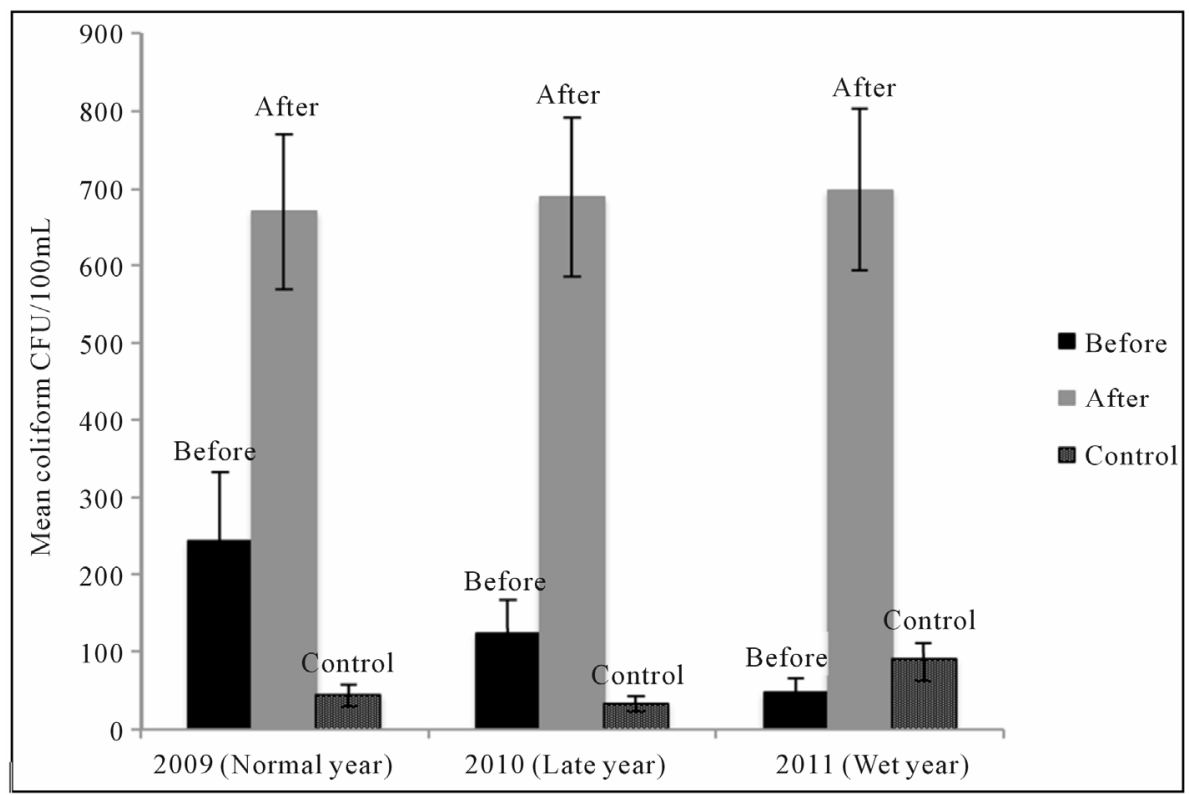

Figure 4. Mean coliform by year.

the stream at Bourland Meadow experienced the same weather conditions, general exposure to wildlife use, occasional recreational visits by forest users, and other environmental influences as the study streams that experienced violations of water quality standards.

In 2011, three additional sites were sampled as ungrazed control sites. These sites are different from the Bourland Meadow ungrazed control site as they are in grazing allotments and are grazed most years. They were not grazed in 2011 as the permittees for those allotments elected to not bring cattle onto the forest. The samples were collected during the summer months that cattle would have been on the forest if the allotments had been grazed in 2011. These sites (BM, BR, and UFG) were sampled in 2009 with cattle on the allotment. In 2009, fifteen "after" samples were collected from the BM site. The mean fecal coliform was $390 \mathrm{CFU} / 100 \mathrm{~mL}$, the mean E. coli was $265 \mathrm{CFU} / 100 \mathrm{~mL}$. In 2011, four samples were collected at the same BM site used in 2009. The mean fecal coliform was less than $26 \mathrm{CFU} / 100 \mathrm{~mL}$, the mean $E$. coli was less than 25 CFU/100mL (Table 2). In 2009, nine "after" samples were collected at the BR sample site. The mean fecal coliform was $153 \mathrm{CFU} / 100 \mathrm{~mL}$, the mean E. coli was $138 \mathrm{CFU} / 100 \mathrm{~mL}$. In 2011, three samples were collected at the same site used in 2009. The mean fecal coliform was $51 \mathrm{CFU} / 100 \mathrm{~mL}$, the mean E. coli was $41 \mathrm{CFU} / 100 \mathrm{~mL}$ (Table 2).

In 2009, seven "after" samples were collected at the UFG sample site. The mean fecal coliform was 340 $\mathrm{CFU} / 100 \mathrm{~mL}$, the mean E. coli was $121 \mathrm{CFU} / 100 \mathrm{~mL}$. In 2011, three samples were collected at the same site used in 2009. The mean fecal coliform was $21 \mathrm{CFU} / 100 \mathrm{~mL}$, the mean E. coli was $18 \mathrm{CFU} / 100 \mathrm{~mL}$ (Table 2).

\subsection{Effects of Year and Grazing on Bacteria Levels}

There was no significant difference in overall $\mathrm{FC} / 100 \mathrm{~mL}$ across the three years (Table 3). There was a significant difference in $\mathrm{FC} / 100 \mathrm{~mL}$ before and after grazing (Table 3, Figure 2). After FC was significantly greater than before and control FC, and there was no significant difference between before and control FC. There was a significant interaction effect of year and before/after (Table $3)$. This interaction is due to significantly greater after $\mathrm{FC} / 100 \mathrm{~mL}$ values in 2010 and 2011 compared to 2009 (Figure 2), while before and control $\mathrm{FC} / 100 \mathrm{~mL}$ values do not significantly change. Additionally, control FC/ $100 \mathrm{~mL}$ values increased in 2011 from 2010 but before and after values do not.

There was a significant difference in overall EC/ $100 \mathrm{~mL}$ across the three years (Table 4). This is driven by after $\mathrm{EC} / 100 \mathrm{~mL}$ measurements in 2010 and 2011 doubling from 2009. There was a significant difference in $\mathrm{EC} / 100 \mathrm{~mL}$ before and after grazing (Table 4, Figure 3). After $\mathrm{EC} / 100 \mathrm{~mL}$ was significantly greater than before and control $\mathrm{EC} / 100 \mathrm{~mL}$, and there was no significant difference between before and control EC. There was a significant interaction effect of year and before/after (Table 4). This is due to greater after $\mathrm{EC} / 100 \mathrm{~mL}$ values in 2010 and 2011 compared to 2009, while before and control values do not significantly change (Figure 3). Additionally, control EC values increase in 2011 compared 2010, while before and after EC values do not significantly 
Table 2. Indicator bacteria levels in 2009 with cattle present compared to the same time period in 2011 without cattle (CFU/ $100 \mathrm{~mL})$.

\begin{tabular}{ccccc}
\hline \multirow{2}{*}{ Sites } & \multicolumn{2}{c}{ 2009-Cattle Present } & \multicolumn{2}{c}{ 2011-No Cattle } \\
\cline { 2 - 5 } & Fecal coliform & E. coli & Fecal lcoliform & E. coli \\
\hline BM & 390 & 265 & 26 & 25 \\
BR & 153 & 138 & 51 & 41 \\
UFG & 340 & 121 & 21 & 18 \\
\hline
\end{tabular}

Table 3. Full factorial analysis of variance $\log$ (fecal coliform/100mL).

\begin{tabular}{ccccc}
\hline Effect & DF & Sum of Squares & F & P \\
\hline Year & 1 & 5.96 & 3.76 & 0.054 \\
Before/After & 2 & 796.57 & 251.36 & $<0.0001$ \\
Date*Before/After & 2 & 10.58 & 3.34 & 0.038 \\
Error & 203 & 326.41 & & \\
\hline
\end{tabular}

Table 4. Full factorial analysis of variance $\log (E$. coli/100mL).

\begin{tabular}{ccccc}
\hline Effect & DF & Sum of Squares & F & P \\
\hline Year & 1 & 7.28 & 4.88 & 0.028 \\
Before/After & 2 & 782.80 & 262.35 & $<0.0001$ \\
Date*Before/After & 2 & 10.30 & 3.45 & 0.034 \\
Error & 206 & 307.33 & & \\
\hline
\end{tabular}

change.

There was no significant difference in overall $\mathrm{TC} /$ $100 \mathrm{~mL}$ across the three years (Table 5). There was a significant difference in $\mathrm{TC} / 100 \mathrm{~mL}$ before and after grazing (Table 5, Figure 4). After TC was significantly greater than before and control $\mathrm{TC}$, and there was no significant difference between before and control TC. There was a significant interaction effect of date and before/after (Table 5). This is due to decrease in before $\mathrm{TC} / 100 \mathrm{~mL}$ values in 2011 as compared to 2010 (Figure 4), while control TC $/ 100 \mathrm{~mL}$ values increased in 2011 as compared to 2010 .

\subsection{Violations of Basin Plan Standard}

Violations of the Basin Plan Standard were documented each of the three years after cattle were present. No violations were found before cattle presence or at control sites. Violations of the State water quality standard for fecal coliform concentration in forest water-bodies were frequent after cattle arrival. For this study, reporting (i.e., five or more samples collected within a 30-day period) periods were only tabulated where a sampling event occurred on the first and/or last day of the last day of the
30 -day period. This conservative method of data analysis documented 41 violations in 2009, 68 violation in 2010, and 52 violations in 2011 of the relevant water quality standard for fecal coliform bacteria contained in the Basin Plan. A more comprehensive analysis (i.e., tabulating all possible 30 -day periods by restarting the 30 -day calendar each day) would likely produce many more violations.

\subsection{Qualitative Field Observations}

\subsubsection{Algae}

Algal growth was observed at eight out the ten study sites exposed to livestock (CSERC field observation, 2009, 2010, 2011). Algal growth was not observed at or near the Bourland Meadow (control) sample site.

\subsubsection{Fecal Coliform and E. coli}

Based on field observations, the higher fecal coliform and E. coli results correlated with cattle presence in or nearby the associated meadow through which the sampled bodies of water flowed (CSERC field observations, 2009, 2010, 2011). Cattle were often observed within the meadow or near the sample water bodies. When cattle 
have not been near a sample area, the bacteria levels start to recede with time.

\subsubsection{Weather}

Table 6 contains the weather data by year from three weather stations located in the Stanislaus National Forest [32].

\section{Discussion}

Our results show that cattle grazing impacts water quality over a wide range of climatic variability. The hypothesis that the large volume water year 2011 would dilute indicator bacteria in streams to an insignificant level was not shown by our data. On the contrary, cattle pollution of watersheds remained at high levels for each of the three summer seasons sampled and in violation of state water quality standards once cattle were present.

Our results are consistent with data published by other research groups. A study by a UC Davis group found ongoing water pollution as well as excessive algae growth throughout the Sierra in 2011, including some areas that received greater than $200 \%$ precipitation [20]. However, that study only sampled sites a single time and did not analyze water before cattle arrived, or on a weekly basis. In our study, we corrected these potential weaknesses in study design by sampling weekly over the summer grazing season.

Other studies of US rangelands have documented that watersheds exposed to cattle grazing can be expected to contain high levels of coliforms and E. coli $[33,34]$. The results from this three-year study show that the concentration of fecal coliform and E. coli in bodies of water was very low before cattle were present on the STF, and then increased dramatically after cattle were present in all three years of the study. Concentration of the coliforms and E. coli did fluctuate from sample to sample. Fecal coliform and E. coli levels may peak when the cattle were directly in or near the associated meadow and sampled streams, and then dilute as cattle move away. Therefore, the time the sample was taken relative to the immediate presence of cattle may explain much of the data variation. This is confirmed by observations in the field (CSERC field observations, 2009, 2010, 2011). These findings are consistent with other studies that have shown free-ranging cattle to be responsible for the majority of the microbial contamination in surface waters of the Sierra Nevada $[22,25]$.

\subsection{Effects of Year and Grazing on Bacteria Levels}

The effect of year was significant for EC; "after" EC levels were higher in 2010 and 2011 as compared to 2009. However, the pattern holds from year to year; "after" concentrations of indicator bacteria are significantly higher than "before" concentrations for each year (P > 0.0001). Sampling different sites each study year, or the amount of time cattle spent near the sample sites may account for the lower concentration of "after" EC detected in 2009 as compared to 2010 and 2011. The effect of year was significant for TC; "before" levels were higher in 2009 as compared to 2010 and 2011. However, the "after" concentrations of indicator bacteria are similar across the years. The lower "before" concentrations of TC in 2010 and 2011 may have been due to the extra precipitation received those years compared to 2009 .

In all three years, measurements of $\mathrm{TC} / 100 \mathrm{~mL}, \mathrm{FC} /$ $100 \mathrm{~mL}$, and $\mathrm{EC} / 100 \mathrm{~mL}$ were higher "after" grazing than "before" grazing or control sites with no grazing, despite

Table 5. Full factorial analysis of variance $\log ($ coliform $/ 100 \mathrm{~mL})$.

\begin{tabular}{ccccc}
\hline Effect & DF & Sum of Squares & F & P \\
\hline Year & 1 & 2.76 & 1.38 & 0.24 \\
Before/After & 2 & 360.66 & 90.10 & $<0.0001$ \\
Date*Before/After & 2 & 40.63 & 10.15 & $<0.0001$ \\
Error & 206 & 431.23 & & \\
\hline
\end{tabular}

Table 6. Weather data by year in $\mathrm{cm}$.

\begin{tabular}{cccc}
\hline Weather year & $\begin{array}{c}\text { Accumulated rain at } 1707 \mathrm{~m} \\
\text { (Rain in April/May only) }\end{array}$ & $\begin{array}{c}\text { Snow depth in May at 2560 } \mathrm{m} \text { in the } \\
\text { Stanislaus River basin (snow water content) }\end{array}$ & $\begin{array}{c}\text { Snow depth in May at } 2560 \mathrm{~m} \text { in the } \\
\text { Tuolumne River basin (snow water content) }\end{array}$ \\
\hline 2009 (Normal year) & $109.35(14.35)$ & $246.38(117.01)$ & $205.74(107.19)$ \\
2010 (Late Spring) & $104.01(25.38)$ & $299.73(143.51)$ & $279.4(129.54)$ \\
2011 (Wet year) & $159.46(10.34)$ & $431.8(204.47)$ & $314.96(185.93)$ \\
\hline
\end{tabular}


high precipitation years in 2010 and 2011. Our results thus support our hypothesis that bacterial contamination from cattle remains consistent from year to year.

In 2009 and 2010 the only control sample site was Bourland Meadow, which is not grazed. In 2011, in addition to sampling Bourland Meadow, three ungrazed sites (that are generally grazed as they were in 2009) were sampled as controls. The level of indicator bacteria is higher at these (normally grazed) control sites in 2011 $(\mathrm{FC} / 100 \mathrm{~mL}=32 \pm 10, \mathrm{EC} / 100 \mathrm{~mL}=28 \pm 9, \mathrm{TC} / 100 \mathrm{~mL}$ $=90 \pm 29$ ), compared to Bourland Meadow (never grazed) in 2009,2010 , and $2011(\mathrm{FC} / 100 \mathrm{~mL}=6 \pm 2$, $\mathrm{EC} / 100 \mathrm{~mL}=5 \pm 2, \mathrm{TC} / 100 \mathrm{~mL}=44 \pm 18$, in 2009 ; $\mathrm{FC} / 100 \mathrm{~mL}=3 \pm 1, \mathrm{EC} / 100 \mathrm{~mL}=2 \pm 0, \mathrm{TC} / 100 \mathrm{~mL}=33$ \pm 4 in 2010 ; and $\mathrm{FC} / 100 \mathrm{~mL}=2, \mathrm{EC} / 100 \mathrm{~mL}=2$, $\mathrm{TC} / 100 \mathrm{~mL}=2$ in 2011). The addition of these control sites in 2011 causing an increase in TC, EC, and FC measurements, while "before" and "after" measurements did not increase, may explain why we see a significant interaction term. When we remove the additional control sites in 2011, the interaction term is no longer significant for fecal coliform and EC. This suggests that the increase in indicator bacterial levels at the control sites in 2011 is driving the interaction of year and sites. Interestingly, even after a $150 \%$ precipitation year such as 2011 , there is still more indicator bacteria found after cattle have grazed an area compared to an always ungrazed area. The baseline level of indicator bacteria may take many years to decline after cattle grazing.

\subsection{Water Quality}

Major surface water quality problems associated with pathogens have been linked with grazing animals, particularly when they are not fenced out from streams [35]. In the Sierra Nevada there are 463 grazing allotments within the 11 National Forests [15]. Nearly 40,000 cattle are transported to summer grazing allotments in the Sierra Nevada each year [36]. In the state of California on the first of January in 2009 and 2010, there were $5,250,000$ and 5,150,000 head of cattle (including calves) [37].

This study was undertaken to analyze the surface water quality of high elevation watersheds exposed to cattle. Cattle manure is known to potentially contain diseasecausing microbes that may affect human health, including viruses, protozoa such as Giardia and Cryptosporidium, and bacteria such as E. coli and Salmonella [21-23]. Indicator bacteria established as markers for fecal contamination include coliforms, fecal coliforms, or E. coli [38]. A positive test for any of these bacteria is an indication that other microorganisms capable of causing human disease may also be present $[38,39]$.
Transmission of Cryptosporidium occurs through oocysts that are shed in the manure of an infected animal. A high percentage of oocysts that are shed in manure can survive for more than half a year [40]. Cryptosporidium oocysts are transported into streams and rivers by precipitation or direct deposition of manure into the waterbodies. The water provides ideal conditions for oocyst survival; however, the oocysts may not simply remain suspended in the water. The oocysts can settle into river sediments where they can survive for prolonged periods of time. Heavy precipitation can resuspend oocysts at a later point [40-42].

A study conducted in Hyogo Prefecture, Japan, collected water samples from 13 rivers serving as tap water sources, using immunomagnetic separation method the samples were tested for Cryptosporidium oocyst. The Cryptosporidium positive rate ranged from $37 \%$ to $100 \%$ when three geographical areas were compared based on agricultural use. The number of cattle in each area was strongly correlated to the rate of contamination with Cryptosporidium $(\mathrm{r}=0.91)$. Genetic analysis by PCRrestriction fragment length polymorphism method confirmed that $C$. parvum oocysts detected was the bovine type, and the degree of contamination with Cryptosporidium in river water was comparable to that of fecal bacteriological indicators [43]. These results are consistent with other watershed studies examining protozoan contamination in watersheds that are also grazed by cattle. The level of parasite contamination in Lake Texoma (bordering Texas and Oklahoma) was examined from 193 surface water samples taken over 27 months. This watershed is a potential drinking water source that is also used for cattle ranching and recreation. They found that the overall occurrence of Cryptosporidium oocysts was higher in both frequency and concentration than Giardia cysts. Cryptosporidium oocysts were found in $99 \%$ and Giardia cysts in $87 \%$ of the samples [44].

Cattle are commonly associated with the zoonotic transmission of Giardia. Transmission of Giardia can occur directly (through the fecal-oral route), or indirectly (through ingestion of contaminated food or water) [45]. Giardia cysts can survive for weeks to months in cold water, and therefore can be present in reservoirs and clear-appearing mountain streams [46]. The pristine appearance of streams makes the introduction of Giardia cysts into forest waters a potential risk for Stanislaus National Forest recreational visitors when untreated water is either intentionally consumed or swallowed accidentally. In British Columbia, Canada, two adjacent watersheds with similar topographical features were studied for Giardia presence. Both the BMID and the VID are actively used for cattle ranching. Cattle have unrestricted access to creeks in the BMID watershed, while access is 
restricted in the VID watershed. Giardia cysts were not found in the water samples collected from the headwaters of either watershed. While Giardia cysts were found in $100 \%$ (70 of 70) of water samples collected downstream of active cattle ranching at the BMID and 97\% (68 of 70) at the VID intake. The difference was that significantly higher levels $(\mathrm{P}<0.05)$ of Giardia cysts were found at the BMID (unrestricted access) intake (7 to 2215 cysts per 100 liters) when compared with that of the VID (restricted access) intake (2 to 114 cysts per 100 liters) [47].

A study by Null et al focused on the hydrologic response of major west-slope watersheds to climate warming in the Sierra Nevada. Their predictive results indicate that a $2^{\circ} \mathrm{C}, 4^{\circ} \mathrm{C}$, and $6^{\circ} \mathrm{C}$ warming will result in an average $3 \%, 6 \%$, and $9 \%$ annual flow reduction [4]. There results are consistent with other studies that have looked at climate change impacts on California's hydrology [4,6, 48]. Watersheds in the central Sierra Nevada (which includes those in the Stanislaus National Forest) may experience longer low flow periods in the future [4]. Low flow conditions are particularly detrimental to the meadow areas [4]. Mountain meadows provide many benefits such as continued flow after snow has melted, improved water quality, habitat for many aquatic and riparian dependent species, and reduced wildfire risk in the forest [4]. Improper grazing can result in damage to meadows and riparian systems. Livestock trampling of streambanks (see Figure 5, picture of trampled streambank) and overgrazing of riparian vegetation leaves streams vulnerable to 1) downcutting that can lead to a lowered water table with reduced water storage, 2) increased water temperature, 3) increased velocity of water runoff, 4) reduced water filtration capacity, and 5) provides the opportunity for undesirable or invasive plants to spread [13-19].

This study tested water samples from streams and

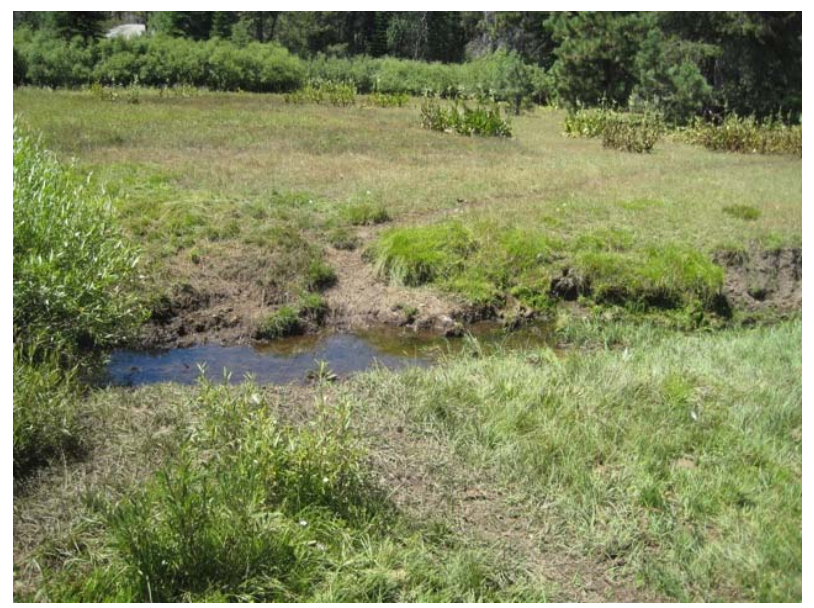

Figure 5. Trampled streambank at LRM sample site, photo taken August 10, 2011. creeks that flowed through meadows within the Stanislaus River and Tuolumne River watersheds during the summers of 2009 (normal precipitation year), 2010 (late spring), and 2011 (150\% precipitation year). During these years, the amount of precipitation received ranged from $100 \%-150 \%$ of an average year. In all of the study years, high levels of $E$. coli and fecal coliform were detected after the commencement of cattle grazing. The peak levels of $E$. coli and fecal coliform were observed to be correlated with times when the cattle were directly in or near the associated meadow through which the sample bodies of water flowed [30, field observations from 2009, 2010, 2011]. This observation may be of particular concern in coming years as the summers in the central Sierra Nevada become longer and hotter. Cattle are likely to spend more time in mountain meadows and riparian areas due to the availability to water, succulent forage, and shade in riparian areas $[12,15,19]$.

\subsection{Algae and Water Quality}

Livestock add nitrogen, phosphorus, organic carbon, iron, and other growth factors for algae to the environment [17]. These nutrients stimulate algae and aquatic growth, which creates an aquatic environment that supports pathogenic microorganisms that may have been introduced [49] (see Figure 6, picture of algae growth). In addition, elevated algae concentrations can lead to the release of toxins, as has occurred with blue green algae in the Swiss Alps that has resulted in cattle deaths [50]. Other cyanobacteria could also become invasive with climate warming, such as Microcystis, which can produce micricystin [51]. Tropical cyanobacterium species (Clindrospermopsis raciborskii which produces clindrospermopsin) is now found in northern freshwater habitats (lakes of Italy, Spain, France and Germany) due

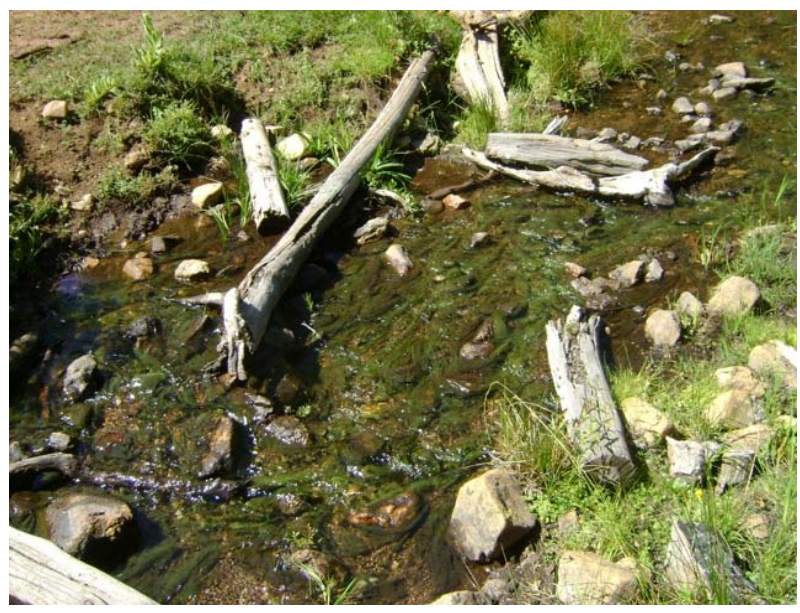

Figure 6. Algal growth just above Bog 1 sample site, photo taken August 4, 2010. 
to warmer temperatures in these areas $[52,53]$.

Algae measurements are important, as water with higher algae levels supports bacterial survival and growth [54]. Derlet et al. evaluated periphytic algal and microbial communities to assess the influence of human and cattle impact on Sierra water quality. They found periphyton algae at $100 \%$ of sites impacted by cattle (C) and $89 \%$ of sites used for recreation (R), but at only $25 \%$ of remote wildlife sites (W). The quantity of algae coverage was only $2 \%$ at $\mathrm{W}$ sites compared to $66 \%$ at $\mathrm{C}$ sites $(\mathrm{P}<0.05)$. The mean level of E. coli $\mathrm{CFU} / \mathrm{gm}$ of algae detected at the sites exposed to cattle was 17,300, 700 at recreational sites and 0 and wilderness sites. Additionally, E. coli at levels $>100 \mathrm{CFU} / 100 \mathrm{~mL}$ was detected in $91 \%$ of water samples sites exposed to cattle, compared to only $8 \%$ of $\mathrm{R}$ sites and $0 \%$ of $\mathrm{W}$ sites $(\mathrm{P}<0.05)$. Derlet et al found that watersheds exposed to cattle had higher periphytic algal biomass and presence of periphyton-attached E. coli [20].

Derlet's results are consistent with other studies that have found alga to support high levels of attached E. coli. Olapade et al. examined a filamentous green alga (Cladophora) that is found along the shores of Lake Michigan during the summer for attached E. coli. The abundance of E. coli on the Cladophora mats was sampled from 11 sites. E. coli was detected in all 63 samples, and the average levels at most beaches ranged from 2700 CFU/100g (wet weight) of Cladophora to $7500 \mathrm{CFU} /$ $100 \mathrm{~g}$ of Cladophora. However, three beaches were found to have site average $E$. coli densities of 12,800, 21,130, and 27,950 CFU/100g of Cladophora while the E. coli levels detected in the lake water was less than 235 CFU/100ml [55].

Attached and benthic algae were not measured, however, observations about algae were noted and photographed. Algal growth was observed at many of the sample sites exposed to summer cattle grazing. Attached and benthic algae was observed at eight of the ten sample sites exposed to summer cattle grazing. Two of the four sites tested for indicator bacteria in 2009 did not have observable algal growth. The two study sites that did not have algal growth had a lower level of bacteria contamination detected than the two sites that did have algal growth in 2009 [26]. The quantity of algal growth was greater at study sites in 2010 and 2011 as compared to 2009 , as was the concentration of indicator bacteria detected. Algal growth was not observed near the Bourland Meadow (control) sample site.

\subsection{Water Standard}

This study documented 161 individual violations of the state water quality standard for fecal coliform during the three years of this study (41 violations in 2009, 68 violations in 2010, and 52 violations in 2011). The violations document the failure of the US Forest Service's "Best Management Practices" (BMPs) to prevent livestock contamination of forest streams in a manner that complies with State water quality standards. Statistical analysis confirmed that the increase in bacteria concentrations during grazing is highly significant when compared to pre-grazing levels, and to control sites where grazing did not occur. The water quality results documents that BMPs applied on the STF are insufficient to meet State water quality standards, and that significant pollution of surface water is resulting from the cattle grazing that is permitted on National Forest lands.

\subsection{Limitations}

The six-hour time limit from the field to the lab for the bacteriological samples collected for this project was not a problematic constraint, but the time requirement was a limiting constraint. The field days were planned with this time constraint in mind so that the field crew had ample time to deliver the bacteriological samples to the lab within that six-hour time limit. This was a limiting constraint in that it prevented the collection of water samples in more remote areas because the samples could not be collected and delivered to the lab within six hours. The only other limiting constraint during the study period was decreased water flow as snowmelt diminished. Two of the sample sites in 2009 (Barn Meadow and Bourland Meadow - control site) had to be moved slightly downstream due to decreased water flow at the original sample location.

The cattle on the Stanislaus National Forest are free range; the study group had no control over where the cattle would be or when they would be there. Allotments may not be grazed some years, so our group had to sample accordingly.

\section{Conclusion}

Consistent results over three very different climatic years demonstrate that cattle grazing does result in a negative impact on water quality in the Sierra Nevada. High levels of indicator bacteria were regularly found after cattle presence in high elevation mountain areas. More than 150 individual violations of California's regulatory water quality standard for bacteria were documented by sampling a very limited number of possible sites. These findings are consistent with other studies indicating that widespread pollution of surface waters is occurring due to livestock grazing on National Forest lands in the Sierra Nevada. 


\section{REFERENCES}

[1] T. I. Storer, R. L. Usinger and D. Lukas, "Sierra Nevada Natural History," University of California, Berkeley, 1963, p. 6.

[2] Sierra Nevada Ecosystem Project, "Status of the Sierra Nevada," Final Report to Congress, Vol. 2, Assessments and Scientific Basis for Management Options, University of CA, Centers for Water \& Wildland Resources, Davis, 2002, p. 557.

[3] D. Carle, "Introduction to Water in California," University of California Press, Berkeley, 2004, pp. 1-32.

[4] S. E. Null, J. H. Viers and J. F. Mount, "Hydrologic Response and Watershed Sensitivity to Climate Warming in California's Sierra Nevada," PLoS One, Vol. 5, No. 4, 2010, p. e9932. doi:10.1371/journal.pone.0009932

[5] C. R. Goldman, "Four Decades of Change in Two Sub Alpine Lakes," Verh Internat Verein Limnology, Vol. 27, 2000, pp. 7-26.

[6] N. L. Miller, K. E. Bashford and E. Strem, "Potential Impacts of Climate Change on California Hydrology," American Water Resources Association, Vol. 39, 2003, pp. 771-784. doi:10.1111/j.1752-1688.2003.tb04404.x

[7] S. Kapnick and A. Hall, "Observed Changes in Sierra Nevada Snowpack: Potential Causes and Concerns," Prepared for the CEC and Cal/EPA. ECE-500-2009-016-D, 2009.

http://www.energy.ca.gov/2009publications/CEC-500-20 09-016/CEC-500-2009-016-D.PDF

[8] J. Medellin-Azuara, J. J. Harou, M. A. Olivares, K. Madani, J. R. Lund, et al., "Adaptability and Adaptations of California's Water Supply System to Dry Climate Warming," Climatic Change, Vol. 87, 2008, pp. 75-90. doi:10.1007/s10584-007-9355-Z

[9] US Census Bureau, "State \& County Quickfacts," 2012, Retrieved 21 April 2012. http://quickfacts.census.gov/qfd/states/06000.html

[10] R. W. Derlet, C. R. Goldman and M. J. Connor, "Reducing the Impact of Summer Cattle Grazing on Water Quality in the Sierra Nevada Mountains of California: A Proposal," Water and Health, Vol. 15, 2010, pp. 347-357.

[11] T. L. Fleischner, "Ecological Costs of Livestock Grazing in Western North America," Conservation Biology, Vol. 8, No. 3, 1994, pp. 629-644. doi:10.1046/j.1523-1739.1994.08030629.x

[12] A. J. Belsky, A. Matzke and S. Uselman, "Survey of Livestock Influences on Stream and Riparian Ecosystems in the Western United States," Soil and Water Conservation, Vol. 54, No. 1, 1999, pp. 419-431.

[13] J. Moore, "Exploring the Highest Sierra," Stanford University Press, Stanford, 2000, pp. 171-209

[14] J. J. Phuhar, W. Knight and R. K. Heitschmidt, "Infiltration Rates and Sediment Production as Influenced by Grazing Systems in the Texas Rolling Plaings," Range Management, Vol. 40, 1987, pp. 240-243. doi: $10.2307 / 3899087$

[15] USDA Forest Service, "Sierra Nevada Forest Plan
Amendment Draft Environmental Impact Statement," Chapter 3, Vol. 2 of 3, Pacific Southwest Region, Vallejo, 2000, pp. 116-142.

[16] C. B. Marlow and T. M. Pogacnik, "Time of Grazing and Cattle-Induced Damage to Streambanks," In: R. R. Johnson, Ed., Riparian Ecosystems and Their Management: Reconciling Conflicting Uses, First North American Riparian Conference, USDA Forest Service, 1985, pp. 279284.

[17] A. Horne and C. Goldman, "Streams and Rivers," In: Limnology, 2nd Edition, McGraw-Hill, New York, 1994, pp. 356-383.

http://www.worldcat.org/search?qt=wikipedia\&q=isbn $\% 3$ A0070236739

[18] J. B. Hauffman, A. S. Thorpe and E. N. J. Brookshire, "Livestock Exclusion and Belowground Ecosystem Responses in Riparian Meadows of Eastern Oregon," Ecological Applications, Vol. 14, No. 6, 2004, pp. 1671-1679. doi:10.1890/03-5083

[19] E. Chaney, W. Elmore and W. S. Platts, "Livestock Grazing on Western Riparian Areas," US Environmental Protection Agency Northwest Resource Information Center, Inc., 1990.

http://www.blm.gov/id/st/en/info/publications/livestock_g razing.html

[20] R. W. Derlet, J. R. Richards, L. L. Tanaka, C. Hayden, K. Ali Ger and C. R. Goldman, "Impact of Summer Cattle Grazing on the Sierra Nevada Watershed: Aquatic Algae and Bacteria," Environmental and Public Health, Vol. 2012, 2012, Article ID: 760108, 7 p.

[21] R. Fayer, "Cryptosporidium: A Water-Borne Zoonotic Parasite," Veterinary Parasitology, Vol. 126, No. 1-2, 2004, pp. 37-56. doi:10.1016/j.vetpar.2004.09.004

[22] R. W. Derlet and J. R. Carlson, "Coliform Bacteria in Sierra Nevada Wilderness Lakes and Streams: What Is the Impact of Backpackers, Pack Animals, and Cattle?" Wilderness and Environmental Medicine, Vol. 17, No. 1, 2006, pp. 15-20. doi:10.1580/PR05-05.1

[23] K. Mattison, A. Shukla, A. Cook, F. Pollari, R. Friendship, D. Kelton, S. Bidawid and J. M. Farber, "Human Noroviruses in Swine and Cattle," Emerging Infectious Diseases, Vol. 13, No. 8, 2007, pp. 1184-1188. doi:10.3201/eid1308.070005

[24] D. G. Renter, J. M. Sargeant, R. D. Oberst and M. Samadpour, "Diversity, Frequency, and Persistence of Escherichia coli O157 Strains from Cattle Environments," Applied Environmental Microbiology, Vol. 69, No. 1, 2003, pp. 542-547. doi:10.1128/AEM.69.1.542-547.2003

[25] R. W. Derlet, K. A. Ger, J. R. Richards and J. R. Carlson, "Risk Factors for Coliform Bacteria in Backcountry Lakes and Streams in the Sierra Nevada Mountains: A 5-Year Study," Wilderness and Environmental Medicine, Vol. 19, No. 2, 2008, pp. 82-90. doi:10.1580/07-WEME-OR-1511.1

[26] L. Myers and J. Kane, "The Impact of Summer Cattle Grazing on Surface Water Quality in High Elevation Mountain Meadows," Water Quality, Exposure and Health, 
Vol. 3, No. 1, 2011, pp. 51-62.

doi:10.1007/s12403-011-0043-x

[27] USDA Forest Service, "Stanislaus National ForestForest Fast Facts," Retrieved 17 August 2009. http://www.fs.fed.us/r5/stanislaus/visitor/

[28] US Fish and Wildlife Service, "Central Valley Watersheds," Retrieved 3 March 2010. http://www.fws.gov/stockton/afrp/watersheds.cfm

[29] USDA Forest Service, "Environmental Assessment: Rangeland Allotments Phase 1," Stanislaus National Forest, Sonora, 2009, p. 2.

[30] L, Myers, "Surface Water Ambient Monitoring Project in the Stanislaus National Forest Quality Assurance Project Plan (QAPP)," Central Sierra Environmental Resource Center (CSERC), Twain Harte, 2009.

http://www.cserc.org/main/news/news_briefs/2010-5.htm

[31] California Regional Water Quality Control Board-Central Valley Region (Basin Plan), "Water Quality Control Plan for the Sacramento and San Joaquin River Basins," Sacramento, 2007, p. III-3.

[32] Department of Water Resources-California Data Exchange Center, 2012. http://cdec.water.ca.gov/cgi-progs/queryF?PCR

[33] H. L. Yers, M. L. Cabrera, M. K. Matthews, D. H. Franklin, J. G. Andrae, D. E. Radcliffe, M. A. McCann, H. A. Kuykendall, C. S. Hoveland and V. H. Calvert, "Phosphorus, sediment and Escherichia coli loads in unfenced streams of the Georgia Piedmont, USA," Environmental Quality, Vol. 34, 2005, pp. 2290-2300.

[34] M. C. Ramos, J. N. Quinton and S. F. Tyrrel, "Effects of Cattle Manure on Erosion Rates and Runoff Water Pollution by Faecal Coliforms," Environmental Management, Vol. 72, 2006, pp. 7531-7539.

[35] R. K. Hubbard, G. L. Newton and G. M. Hill, "Water Quality and the Grazing Animal," Animal Science, Vol. 82, 2004, pp. 255-263.

[36] T. Knudson, "Livestock Waste Found to FOUL SIERRA Waters," The Sacramento Bee, Bee exclusive, 2010, p. 1.

[37] USDA National Agricultural Statistics Service, "Census of Agriculture-Quick Stats," 2012.

http://quickstats.nass.usda.gov/

[38] American Public Health Association, "Microbiologic Examination," In: L. S. Clesceri, Ed., Standard Methods for the Examination of Water and Wastewater, 20th Edition, United Book Press Inc., Baltimore, 1998, pp. 1-140.

[39] A. Rompre, P. Servais, J. Baudart, M. R. de-Roubin and P. Laurent, "Detection and Enumeration of Coliforms in Drinking Water: Current Methods and Emerging Approaches," Microbiological Methods, Vol. 49, 2002, pp. 31-54. doi:10.1016/S0167-7012(01)00351-7

[40] L. J. Robertson, A. T. Campbel and H. V. Smith, "Survival of Cryptosporidium Parvum Oocysts under Various Environmental Pressures," Applied Environmental Microbiology, Vol. 58, No. 11, 1992, pp. 3494-3500.

[41] V. Roquet, F. Homer, J. M. Bringnon, P. Bonne and J.
Cavard, "Source and Occurrence of Giardia and Cryptosporidium in Paris Rivers," Water Science Technology, Vol. 41, No. 7, 2000, pp. 79-86.

[42] I. R. Lake, G. Bentham, R. S. Kovats and G. L. Nichols, "Effects of Weather and River Flow on Cryptosporidiosis," Water and Health, Vol. 3, No. 4, 2005, pp. 469-474.

[43] K. Ono, H, Tsuji, K. Shimada, K. Masuda and T. Endo, "Isolation and Incidence of Cryptosporidium and Giardia from River Water," Kansenshogaku Zasshi, Vol. 7, No. 3, 2001, pp. 201-208.

[44] A. Keeley and B. R. Faulkner, "Influence of Land Use and Watershed Characteristics on Protozoa Contamination in a Potential Drinking Water Resources Reservoir," Water Resources, Vol. 42, No. 10-11, 2008, pp. $2803-$ 2813.

[45] H. Sprong, S. M. Caccio and J. W. van der Giessen, "Identification of Zoonotic Genotypes of Giardia duodenalis. Laboratory for Zoonoses and Environmental Microbiology, National Institute for Public Health and Environment (RIVM)," PLoS Neglected Tropical Diseases, Vol. 3, No. 12, 2009, p. 558.

[46] D. B. Huang and A. C. White, "An Updated Review on Cryptosporidium and Giardia," Gastroenterol Clinic North America, Vol. 2, 2006, pp. 291-314. doi:10.1016/i.gtc.2006.03.006

[47] C. Ong, W. Moorehead, A. Ross and J. Renton-Isaac, "Studies of Giardia spp. and Crytosporidium spp. in Two Adjacent Watersheds," Applied Environmental Microbiology, Vol. 62, No. 8, 1996, pp. 2798-2805.

[48] D. P. Lettenmaier and T. Y. Gan, "Hydrologic Sensitivities of the Sacramento-San Joaquin River Basin, California, to Global Warming," Water Resources Research, Vol. 26, 1990, pp. 69-86.

[49] M. Jasson, A. K. Bergstrom, D. Lymer, K. Verde and J. Karlsson, "Bacterioplankton Growth and Nutrient Use Efficiencies under Variable Organic Carbon and Inorganic Phosphorus Rations," Microbial Ecology, Vol. 52, 2006, pp. 358-364. doi:10.1007/s00248-006-9013-4

[50] K. Mez, K. A. Beattie, G. A. Codd, K. Hanselmann, B. Hauser, H. Naegeli and H. R. Preisig, "Identification of a Microcystin in Benthic Cyanobacteria Linked to Cattle Deaths on Alpine Pastures in Switzerland," European Journal Psychology, Vol. 32, 1997, pp. 111-117. doi: $10.1080 / 09670269710001737029$

[51] K. D. Jöhnk, J. Huisman, J. Sharples, B. Sommeijer, P. M. Visser and J. M. Stroom, "Summer Heatwaves Promote Blooms of Harmful Cyanobacteria," Global Chang Biology, Vol. 14, 2008, pp. 495-512. doi:10.1111/j.1365-2486.2007.01510.x

[52] L. Brient, M. Lengronne, M. Bormans and J. Fastner, "Short Communication of Cylindrospermopsin in Freshwater in France," Environmental Toxicology, Vol. 24, No. 4, 2008, pp. 415-420. doi:10.1002/tox.20439

[53] C. Wiedner, J. Rücker, R. Brüggemann and B. Nixdorf, "Climate Change Affects Timing and Size of Populations of an Invasive Cyanobacterium in Temperate Regions," Oecologia, Vol. 152, 2007, pp. 473-484. 

Annual Climatic Conditions

Doi:10.1007/S00442-007-0683-5

[54] W. Tao, K. J. Hall and W. Ramey, "Effects of Influent Strength on Microorganisms in Surface Flow Mesocosm Wetlands," Water Research, Vol. 41, 2007, pp. 45574565. doi:10.1016/j.watres.2007.06.031

[55] O. A. Olapade, M. M. Depas, E. T. Jensen and S. L.
McLellan, "Microbial Communities and Fecal Indicator Bacteria Associated with Cladophora Mats on Beach Sites along Lake Michigan Shores," Applied and Environmental Microbiology, Vol. 72, No. 3, 2006, pp. 19321938. doi:10.1128/AEM.72.3.1932-1938.2006 